\title{
Quality evaluation of simvastatin compounded capsules
}

\author{
Flávia Dias Marques-Marinho, ${ }^{1, *}$, José Carlos da Costa Zanon², Emilia Sakurai ${ }^{3}$, Ilka Afonso Reis ${ }^{3}$, \\ Angélica Alves Lima ${ }^{4}$, Cristina Duarte Vianna-Soares ${ }^{1}$
}

\begin{abstract}
${ }^{1}$ Department of Pharmaceutical Products, Faculty of Pharmacy, Federal University of Minas Gerais, Belo Horizonte, MG, ${ }^{2}$ Ouro Cordis Clinic, Santa Casa Hospital, Ouro Preto, MG, ${ }^{3}$ Department of Statistics, ICEx, Federal University of Minas Gerais, ${ }^{4}$ Department of Clinical Analyses, Pharmacy School, Federal University of Ouro Preto, Ouro Preto, MG
\end{abstract}

\begin{abstract}
Simvastatin is commercially available as tablets and compounded capsules in Brazil. Very few reports regarding these capsules' quality, and consequently their efficacy, are available. The pharmaceutical quality of 30 batches of $20 \mathrm{mg}$ simvastatin capsules from the market was evaluated by weight determination, content uniformity, disintegration (Brazilian Pharmacopeia), assay and dissolution test (USP32 tablet monograph). A HPLC method was developed for assay, content uniformity and dissolution test, and specifications were also established. Out of the 30 batches evaluated, 29 showed capsule disintegration within $45 \mathrm{~min}$ and individual weight variation was within $\pm 10 \%$ or $\pm 7.5 \%$ relative to average weight, for $\leq$ or $>300 \mathrm{mg}$, respectively. Only 27 batches met dissolution test criteria with values $\geq 80 \%$ of the labeled amount in $45 \mathrm{~min} ; 21$ batches showed simvastatin content between $90.0-110.0 \%$ of the labeled amount and 19 batches had at least 9 out of 10 capsules with content uniformity values between 85.0$115.0 \%$ of the labeled amount with $\mathrm{RSD} \leq 6.0 \%$. Only 14 of all (30) batches fully met pharmacopeial quality standards. The establishment of test conditions and specification parameters for simvastatin capsules showed that there are relevant pharmacopeial quality differences between batches compounded by different pharmacies. For $53.33 \%$ of the tested products hypercholesterolemic treatment efficacy may be compromised.
\end{abstract}

Uniterms: Compounded simvastatin capsules. Quality control. RP-HPLC.

No Brasil, a sinvastatina está comercialmente disponível na forma de comprimidos e cápsulas manipuladas. Poucos relatos estão disponíveis sobre a qualidade e, consequentemente, a eficácia dessas cápsulas. A qualidade de 30 lotes de sinvastatina $20 \mathrm{mg}$ cápsulas do mercado foi avaliada através da determinação de peso, uniformidade de conteúdo, desintegração (Farmacopéia Brasileira), doseamento e teste de dissolução (monografia comprimidos USP32). Método por CLAE foi desenvolvido para o doseamento, uniformidade de conteúdo e teste de dissolução; além disso, especificações foram estabelecidas. Dos 30 lotes avaliados, 29 apresentaram desintegração da cápsula até 45 min e a variação do peso individual foi $\pm 10 \%$ ou $\pm 7,5 \%$ em relação ao peso médio, se $\leq$ ou $>300 \mathrm{mg}$, respectivamente. Apenas 27 lotes preencheram os critérios do teste de dissolução com valores $\geq 80 \%$ da quantidade rotulada, em 45 min, 21 lotes apresentaram conteúdo de sinvastatina entre $90,0-110,0 \%$ do valor rotulado e 19 lotes apresentaram pelo menos 9 em 10 cápsulas, com valores de uniformidade de conteúdo entre 85,0 - $115,0 \%$ da quantidade rotulada com RSD $\leq 6,0 \%$. Apenas 14 de todos os lotes (30) atenderam completamente os padrões de qualidade farmacopéicos. O estabelecimento das condições para os testes e de especificações para os parâmetros das cápsulas de sinvastatina mostrou que houve diferenças relevantes na qualidade farmacopeica entre os lotes das cápsulas manipuladas por distintas farmácias. A eficácia do tratamento hipercolesterolêmico poderia estar comprometida para 53,33\% dos produtos testados.

Unitermos: Sinvastatina. Cápsulas manipuladas. Controle de qualidade. FR-CLAE.

\footnotetext{
*Correspondence: F.D. Marques-Marinho. Departamento de Produtos Farmacêuticos, Faculdade de Farmácia, Universidade Federal de Minas Gerais. Av. Pres. Antônio Carlos, 6627 - 31270-901 - Belo Horizonte, MG, Brasil. Email: flaviadmar@hotmail.com
} 


\section{INTRODUCTION}

Simvastatin (SIM, Figure 1) is a lipid lowering agent widely used worldwide for the treatment of hypercholesterolemia and for reducing morbidity and mortality associated with chronic heart disease (The $4 \mathrm{~S}, 1994)$. It is commercially available in tablet and capsule dosage forms. SIM capsules are manufactured in Brazil by compounding pharmacies.

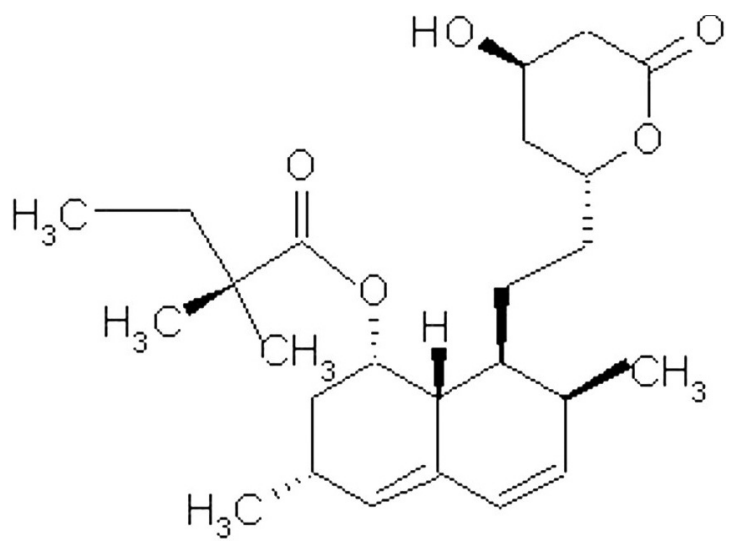

FIGURE 1 - Simvastatin chemical structure.

The pharmaceutical sector reached its most dominant in the late 1980s when it became the focus of attention from the regulatory agencies (Bertollo, 2008). The creation of the National Sanitary Surveillance Agency/ANVISA, the Brazilian regulatory authority, led to greater concern over health and safety of products, health services, production supervision and drug sales (Brasil, 1999). In 2000, ANVISA published its first resolution act, RDC 33, aimed at achieving harmonization in the compounding pharmacies sector (Brasil, 2000). It became mandatory to evaluate the compounded products by the pharmacies with respect to their physico-chemical quality and different characteristics. The pharmacies had to adjust to this requirement in order to remain in the market, or else shut down. Only six years later, RDC 33 resolutions was replaced by the more comprehensive RDC 214 (Brasil, 2006). Amid much controversy over the latter, another regulation RDC 67 was subsequently published in 2007 (Brasil, 2007) and later updated with the current RDC 87 amendment in 2008 (Brasil, 2008). In this scenario, ANVISA quality requirements for products and services offered by compounding pharmacies increased upon each new RDC release, leading to the commercial survival only of those businesses who could adapt and comply. Standardized procedures, process monitoring, quality management, employee training and more rigorous quality control numbered among the requirements. A high investment in equipment, personnel training and hiring of outsourced services was necessary. Not all pharmacies could afford to meet all the demands to incorporate changes. Nevertheless, the importance of these requirements to share professional responsibility and ensure greater health safety for patients was acknowledged.

For the last ten years compounding pharmacies have been governed by specific legislation, although many doubts about product quality, safety and efficacy still remain. Quality control is hampered by the absence of specific monographs for compounded products, leading to a lack of standardization in quality evaluation by accredited analysis laboratories for health, as well as, by ANVISA (Brasil, 1999a). Despite the prevailing limitations in the compounding pharmaceutical field, the number of new pharmacies has increased in recent years, according to ANVISA and Compounding Pharmacists National Association/ANFARMAG data (ANVISA, 2005). Today, the importance of compounding pharmacies in the communities is incontestable. Compounded capsules can be dose personalized, less expensive than industrialized tablets, and economically more attractive for the population. In view of the social importance of the sector, the quality of SIM compounded capsules was evaluated in the present study given that it can directly influence the safety and efficacy of products.

\section{MATERIAL AND METHODS}

Simvastatin USP reference standard (RS, lot I0D382, 99.4\% purity label claim, United States Pharmacopeia, Rockville, MD, USA), methanol HPLC grade (Tedia, Fairfield, OH, USA), phosphoric acid 85\% (Merck, Darmstadt, Germany), sodium dodecyl sulphate (SDS; Pharmacopéia Ativos Magistrais, Barueri, SP, Brazil), sodium hydroxide (J.T. Baker, Phillipsburg, NJ, USA) and monobasic sodium phosphate (Vetec, Rio de Janeiro, RJ, Brazil) were used as received. Distilled or ultrapurified water (Milli-Q-Plus, Millipore, Bedford, MA, USA) was used when necessary.

Simvastatin $20 \mathrm{mg}$ capsule batches were randomly acquired (April to July, 2009) from thirty compounding pharmacies in regard to site location in different regions of Belo Horizonte, southeast of Brazil. Six batches were donated and twenty four were purchased in the market. During the study, the compounded capsules were stored according to labeled instructions and when not specified were stored in a dry and fresh place at ambient temperature. Batch characteristics (color and size) and capsule unit price are described in Table I. 
All capsules batches were submitted to weight determination, disintegration, content uniformity assessments and evaluated according to Brazilian Pharmacopeia general methods (Farmacopéia Brasileira, 1988, 1996). For weight determination, twenty units of each batch were individually weighed on an analytical microbalance (BP210D, Sartorius, Edgewood, NY, USA). The average weight (AW) was calculated along with individual capsule variation relative to AW. Specified individual variation could be less than $\pm 10 \%$ or $\pm 7.5 \%$ for $\mathrm{AW} \leq 300 \mathrm{mg}$ or $\mathrm{AW}>300 \mathrm{mg}$, respectively. If two or more units failed to meet the limits, the capsule $(n=20)$ contents were removed and their weight was determined by mass difference. A maximum of two units outside the original range was tolerated, but their variation had to be less than double the specified limits. Disintegration time was determined using six units from each batch in an Erweka disintegrator (ZT3, Heusenstamm, Germany) equipped with chronometer and thermostatic bath at $37 \pm 1^{\circ} \mathrm{C}$. The disintegration time limit for all capsules to completely disintegrate was $45 \mathrm{~min}$. Content uniformity was performed on ten units from each batch. SIM was individually assayed by developed HPLC method after dilution in a $50 \mathrm{~mL}$ volumetric flask and successive dilution in methanol until SIM $40 \mu \mathrm{g} / \mathrm{mL}$. Acceptance criteria were no more than one unit outside the specified limit of $85.0 \%-115.0 \%$ of the labeled amount (LA). However, the individual value had to fall within 75.0$125.0 \%$ LA and the relative standard deviation (RSD) had to be less than or equal to $6.0 \%$. For assay and dissolution test conditions, the USP32 SIM tablet monograph was observed (United, 2009). For assay, an adequate SIM mass, equivalent to one AW, was accurately weighed (triplicate) and successively diluted with methanol (filtered, if necessary) in order to obtain SIM $40 \mu \mathrm{g} / \mathrm{mL}$ for injection into the chromatograph. The criterion was $90.0-110.0 \%$ LA. The dissolution test (first stage only) was performed for six capsule units from each batch (DT80, Erweka, Heusenstamm, Germany) with USP apparatus 2 (paddle) at $75 \mathrm{rpm}$ for $45 \mathrm{~min}$ using stainless steel sinkers (Flowscience, Cotia, SP, Brazil) to keep the capsules at the vessel bottom. Monobasic sodium phosphate at $0.01 \mathrm{M}$ containing $0.50 \% \mathrm{SDS}, \mathrm{pH}$ adjusted to $7(40 \% \mathrm{w} / \mathrm{v}$ sodium hydroxide), $900 \mathrm{~mL}, 37 \pm 0.5^{\circ} \mathrm{C}$ was used as the dissolution medium and selected $Q$ value was $75 \%$. Aliquots of $5.0 \mathrm{~mL}$ were withdrawn from the dissolution vessels, filtered and injected into the chromatograph. The requirement for the first stage of the dissolution test was that each unit had to release at least $80 \% \mathrm{LA}(\mathrm{Q}+5 \%)$. A validated RP-HPLC method developed in-house was used to determine SIM in assay, content uniformity and dissolution test on a HP1200 quaternary pump liquid chromatograph (Agilent, Palo Alto, CA, USA) using methanol and $0.1 \%$ phosphoric acid $(80: 20 \mathrm{v} / \mathrm{v})$ as mobile phase, at $30^{\circ} \mathrm{C}, 1.5 \mathrm{~mL} / \mathrm{min}, \mathrm{UV} /$ DAD detection $\lambda 238 \mathrm{~nm}$, with automatic injector fitted at $10 \mu \mathrm{l}$ and a $\mathrm{C} 8$ endcapped column $(250 \mathrm{x} 4 \mathrm{~mm}, 5 \mu \mathrm{m}$, Merck, Darmstadt, Germany). All standard and sample solutions were filtered through a $0.45 \mu \mathrm{m}$ filter membrane (Minisart RC15 Sartorius, Goettingen, Germany) before injection.

Calibration curves were constructed from SIM methanolic solutions $(n=3)$ prepared at $4,20,40,60$, $80 \mu \mathrm{g} / \mathrm{mL}$ for assay/content uniformity and from SIM in dissolution medium solutions $(\mathrm{n}=3)$ prepared at $2,10,18$, $26,34 \mu \mathrm{g} / \mathrm{mL}$ for the dissolution test. The respective curve equations were used to determine SIM in assay/content uniformity and the dissolution test. The R statistical software was used to evaluate the curve equation model, normality and homoscedasticity $(\alpha=0.05)$ by the weighted least squares method, Shapiro-Wilk and Levene tests, respectively (Souza, Junqueira, 2005). Data were treated by studentized residual model in order to remove outliers (residues greater than 3.0) where necessary. Intercept, correlation coefficients ( $\mathrm{r}$ ) and \% RSD were calculated and the chromatographic parameters of asymmetry (As), retention factor $(\mathrm{k})$ and retention time $(\mathrm{t})$ were observed (Green, 1996; Jenke, 1996; Snyder, Kirkland, Glajch, 1997; United, 2009a). Results were considered significant when the corresponding $p$ value was less than 0.05 .

Selectivity was evaluated through peak purity analysis by UV/DAD spectra of capsule samples. In a representative capsule sample (acquired from the university pharmacy, rather than the 30 pharmacies), SIM 10, 20 and $40 \mathrm{mg}$ correspondent masses were adequately diluted to obtain precision evaluation at three levels of concentrations: $20,40,80 \mu \mathrm{g} / \mathrm{mL}(\mathrm{n}=3)$, respectively. Accuracy was assessed by recovery of SIM standard (10, 20, $40 \mathrm{mg}, \mathrm{n}=3$ ) added to SIM capsule sample solution and properly diluted within the linear range $(20,40,80$ $\mu \mathrm{g} / \mathrm{mL})$. Robustness was assessed by variations in flow rate $( \pm 0.1 \mathrm{~mL} / \mathrm{min})$, methanol ratio $( \pm 2 \%)$ and temperature $\left( \pm 5^{\circ} \mathrm{C}\right)$ using SIM $40 \mu \mathrm{g} / \mathrm{mL}(\mathrm{n}=5)$.

\section{RESULTS AND DISCUSSION}

The qualitative composition of all donated SIM capsule batches were provided by the respective pharmacies. Compounded capsule unit price (Table I) ranged from US\$0.13 to US\$0.27 among the pharmacies, a cost approximately $5.6 \%$ to $11.7 \%$, respectively, of Zocor ${ }^{\circledR}$ tablet unit prices (US\$2.30). None of the capsule batches showed any problems regarding physical aspect. 
TABLE I - Description of simvastatin $20 \mathrm{mg}$ capsule batches acquired from thirty compounding pharmacies

\begin{tabular}{|c|c|c|c|}
\hline $\begin{array}{l}\text { Pharmacy } \\
\text { (P) }\end{array}$ & $\begin{array}{c}\text { Capsule } \\
\text { price (US\$) }\end{array}$ & $\begin{array}{l}\text { Capsule color; } \\
\text { size }\end{array}$ & $\begin{array}{l}\text { Storage } \\
\text { conditions }\end{array}$ \\
\hline 1 & $\mathrm{D}^{\mathrm{b}}$ & red/white; 4 & $\mathrm{NS}^{\mathrm{c}}$ \\
\hline 2 & $\mathrm{D}$ & white/white; 1 & $\begin{array}{c}\text { Also, protect } \\
\text { from light and } \\
\text { humidity }\end{array}$ \\
\hline 3 & $\mathrm{D}$ & green/white; 4 & NS \\
\hline 4 & $\mathrm{D}$ & blue/white; 1 & NS \\
\hline 5 & $\mathrm{D}$ & green/white; 3 & $\begin{array}{c}\text { Keep } \\
\text { refrigerated. }\end{array}$ \\
\hline 6 & $\mathrm{D}$ & green/white; 4 & $\begin{array}{c}\text { Keep } \\
\text { refrigerated. }\end{array}$ \\
\hline 7 & 0.20 & green/white; 4 & NS \\
\hline 8 & 0.17 & transparent; 4 & NS \\
\hline 9 & 0.26 & blue/white; 4 & $\begin{array}{l}\text { Keep in dry } \\
\text { place }\end{array}$ \\
\hline 10 & 0.27 & red/white; 3 & NS \\
\hline 11 & 0.25 & orange/yellow; 2 & NS \\
\hline 12 & 0.22 & green/white; 3 & NS \\
\hline 13 & 0.22 & bordeaux/white; 3 & $\begin{array}{l}\text { Keep well } \\
\text { closed }\end{array}$ \\
\hline 14 & 0.23 & blue/white; 3 & NS \\
\hline 15 & 0.17 & bordeaux/white; 2 & NS \\
\hline 16 & 0.14 & bordeaux/white; 3 & NS \\
\hline 17 & 0.19 & dark blue/white; 3 & NS \\
\hline 18 & 0.17 & blue/white; 2 & $\begin{array}{l}\text { Protect from } \\
\text { heat and } \\
\text { humidity }\end{array}$ \\
\hline 19 & 0.18 & green/white; 4 & NS \\
\hline 20 & 0.18 & transparent; 3 & NS \\
\hline 21 & 0.13 & white; 3 & NS \\
\hline 22 & 0.14 & blue/gray; 4 & NS \\
\hline 23 & 0.23 & blue/white; 3 & NS \\
\hline 24 & 0.18 & blue/white; 3 & $\begin{array}{l}\text { Protect from } \\
\text { heat and } \\
\text { humidity }\end{array}$ \\
\hline 25 & 0.23 & blue/white; 4 & $\begin{array}{l}\text { Protect from } \\
\text { heat and } \\
\text { humidity }\end{array}$ \\
\hline 26 & 0.17 & blue/white; 4 & NS \\
\hline 27 & 0.23 & green/white; 2 & NS \\
\hline 28 & 0.13 & green/white; 4 & NS \\
\hline 29 & 0.15 & white; 4 & NS \\
\hline 30 & 0.20 & transparent; 4 & NS \\
\hline
\end{tabular}

a: Zocor® $20 \mathrm{mg}$ tablet unit price US\$2.30, for comparison. Currency conversion BRL to US dollar; b: D, donation; c: NS, not specified.
A validated RP-HPLC method for SIM determination showed adequate selectivity (Ermer, 2001; Shabir, 2003). Chromatographic peak purity $(\geq 99.8 \%)$ was provided by UV/DAD spectra (Figure 2a,b, details).

Satisfactory results were obtained for precision and accuracy (Table II) with RSD values less than $2.0 \%$ and recovery levels between $98.0-102.0 \%$, respectively. The HPLC method was shown to be robust, since there was no statistical difference by ANOVA ( $p$ value $>0.05$ ) after variation in flow rate $(p=0.71)$, methanol ratio $(p=0.06)$ and temperature $(p=0.11)$.

The response-concentration relationship for assay/ content uniformity and dissolution test curves obtained by the weighted least squares method was expressed by a quadratic and linear equation, respectively. Both curves demonstrated adequate normality (Shapiro-Wilk) and homoscedasticity (Levene) for $p$ value $>0.05$. Intercept was not significantly different from zero ( $p$ value $>0.05)$ for the quadratic model for assay/content uniformity. In cases of significant $p$ value less than 0.05 , the percentage of the intercept (relative to the $100 \%$ analyte level) up to $\pm 2 \%$ is accepted, as observed in the linear model for the dissolution test (Green, 1996; Jenke, 1996). Correlation coefficients (r) were greater than 0.999 for SIM assay/ content uniformity curve (Jenke, 1996) or greater than 0.98 for the SIM dissolution curve (United, 2009a) and in both cases, RSD values were less than 2.0\% (Jenke, 1996). Results of regression analysis are summarized in Table III.

SIM peak eluted with retention factors, $\mathrm{k} 2.896$ (5.622 $\mathrm{min})$ and $4.613(5.676 \mathrm{~min})(\mathrm{k}>2)$, asymmetry factors 0.96 and $1.02($ As $<1.2)$ for assay/content uniformity (Figure 2a) and dissolution test, respectively (Figure 2b) were appropriate (Snyder, Kirkland, Glajch, 1997).

The weight determination test results for the thirty batches are shown in Table IV. Four batches (P12, P17, P19 and P20) had to be retested by the removal of content, whereas one batch (P19) did not meet the weight requirements because it contained more than two units (five) with an individual variation greater than $10 \% \mathrm{AW}$. Hence, P19 batch showed problems with homogeneity of powder distribution inside the capsules. For the disintegration test, only batch (P4) did not meet the criteria because its capsules did not disintegrate at all within 45 min. The capsules ended swollen and soft suggesting a formulation problem, probably related to a high percentage $(30 \% \mathrm{w} / \mathrm{w})$ of carboxymethylcellulose (CMC), a gel forming agent (Rowe, Sheskey, Quinn, 2009).

For content uniformity ( $\mathrm{n}=30$, Table IV), only nineteen $(63.3 \%)$ batches met the requirements of within 85.0-115.0\% LA (87.2-106.3\%) and RSD values were less than or equal to $6.0(1.9-6.0 \%)$. Ten batches (P4, P10, P12, 

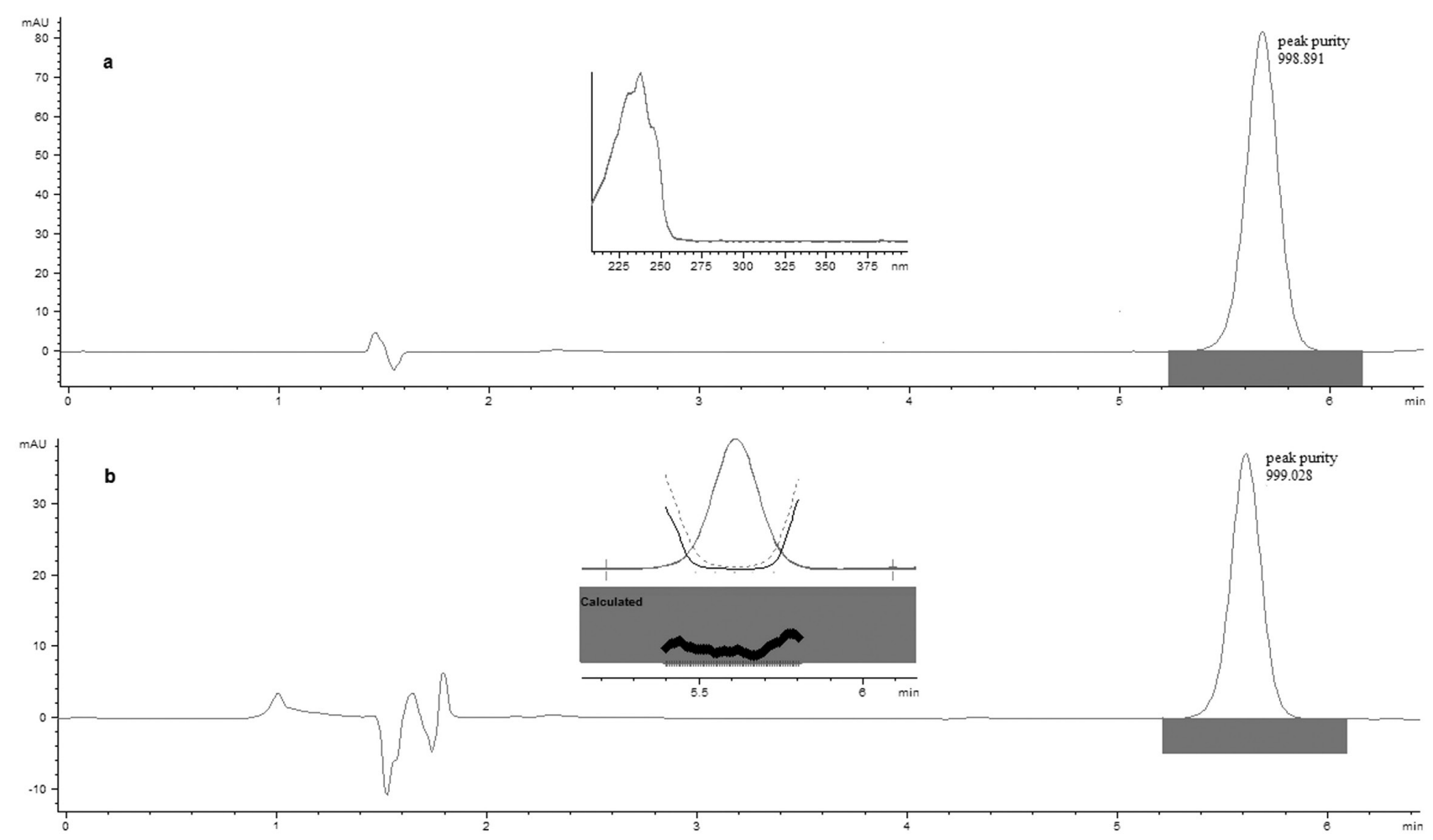

FIGURE 2 - SIM representative chromatograms for (a) assay/content uniformity, detail: SIM UV/DAD spectrum and (b) dissolution test, detail peak: purity curves. Chromatographic conditions: $\mathrm{C}_{8}$ endcapped $(250 \times 4 \mathrm{~mm}, 5 \mu \mathrm{m}) 30^{\circ} \mathrm{C}, \lambda 238 \mathrm{~nm}$, methanol:0.1\% phosphoric acid $(80: 20 \mathrm{v} / \mathrm{v}), 1.5 \mathrm{~mL} / \mathrm{min}$, injection volume $10 \mu \mathrm{l}$. Dissolution conditions: $0.5 \%$ SDS in $0.01 \mathrm{M}$ monobasic sodium phosphate $\mathrm{pH} 7\left(900 \mathrm{~mL}, 37 \pm 0.5^{\circ} \mathrm{C}\right)$, paddles, $75 \mathrm{rpm}, 45 \mathrm{~min}$.

TABLE II - HPLC precision and accuracy results for SIM $20 \mathrm{mg}$ compounded capsules provided by the university pharmacy (chromatographic conditions, Figure 2)

\begin{tabular}{|c|c|c|c|c|}
\hline \multirow{3}{*}{\multicolumn{2}{|c|}{ Validation parameters }} & \multicolumn{3}{|c|}{ SIM amount/capsule } \\
\hline & & \multicolumn{3}{|c|}{ SIM, mg (RSD) } \\
\hline & & 10 & 20 & 40 \\
\hline \multicolumn{5}{|l|}{ Precision } \\
\hline \multicolumn{5}{|c|}{ Intraday $(n=3)$} \\
\hline \multirow[t]{3}{*}{ Analysts } & I & $8.7(1.6)$ & $17.6(0.9)$ & $34.9(1.2)$ \\
\hline & I & $8.8(1.3)$ & $17.9(1.1)$ & $34.2(0.1)$ \\
\hline & II & $8.9(1.9)$ & $17.5(1.1)$ & $34.0(2.0)$ \\
\hline \multicolumn{2}{|c|}{ Interday $(\mathrm{n}=9)$} & $8.8(1.7)$ & $17.7(1.4)$ & $34.4(1.7)$ \\
\hline \multicolumn{5}{|c|}{ Accuracy $(n=3)$} \\
\hline \multicolumn{2}{|c|}{ Standard addition } & $9.9(0.8)$ & $19.7(0.4)$ & $39.4(0.3)$ \\
\hline \multicolumn{2}{|c|}{ \%Recovery } & 99.2 & 98.4 & 98.6 \\
\hline
\end{tabular}

a: RSD, relative standard deviation.

P18, P19, P21, P22, P27-29) out of eleven, which failed the test, had an RSD greater than 6.0\% (6.2-19.7\%) and one batch (P25) had three units below 85.0\% LA despite having a RSD lower than $5.0 \%$. These problems related to high \%LA variability reflected either inadequate powder homogenization or poor capsule powder distribution leading to drug content differences between units within the same batch. Assay results (Table IV) show that twenty- 
TABLE III - Statistical regression results by ANOVA for SIM assay/content uniformity and dissolution test by HPLC (chromatographic conditions, Figure 2)

\begin{tabular}{lll}
\hline Parameter & Assay/Content uniformity & Dissolution $^{\mathrm{a}}$ tes $^{\mathrm{b}}$ \\
\hline Range $(\mu \mathrm{g} / \mathrm{mL})$ & $4-80$ & $2-34$ \\
Regression equation & $\mathrm{y}=0.0122 \mathrm{x}^{2}+22.1837 \mathrm{x}-0.1805$ & $\mathrm{y}=21.5099 \mathrm{x}+4.2288$ \\
$p$-value regression & $2.2 \times 10^{-16}$ & $2.2 \times 10^{-16}$ \\
\%RSD & 0.47 & 0.22 \\
Correlation coefficient, $\mathrm{r}$ & 0.9999 & 0.9999 \\
Intercept $^{\mathrm{b}}$ value $^{\mathrm{c}}$ & 0.79 & 0.003 \\
Shapiro-Wilk $(p \text { value })^{\mathrm{d}}$ & $0.97(0.81)$ & $0.92(0.26)$ \\
Levene $\left((\boldsymbol{p} \text { value })^{\mathrm{d}}\right.$ & $0.49(0.74)$ & $0.24(0.91)$ \\
\hline
\end{tabular}
a: diluent methanol; b: diluent $0.5 \%$ SDS in $0.01 \mathrm{M}$ monobasic sodium phosphate (pH 7), c: significant for $p$ value $<0.05$, d: no statistical evidence of problems for $p$ value $>0.05$.

TABLE IV - Quality control test results for thirty batches of simvastatin $20 \mathrm{mg}$ compounded capsules (conditions, Figure 2)

\begin{tabular}{|c|c|c|c|c|c|}
\hline $\begin{array}{l}\text { Pharmacy } \\
\text { (P) }\end{array}$ & $\begin{array}{l}\text { Mean weight }{ }^{\mathrm{a}} \\
\text { (mg) }\end{array}$ & $\begin{array}{l}\text { Disintegration time } \\
\text { (min) }\end{array}$ & $\begin{array}{c}\text { Content uniformity } \\
(\%)\end{array}$ & $\begin{array}{l}\text { Assay }^{\mathrm{a}} \\
(\%)\end{array}$ & $\begin{array}{l}\text { Dissolution }{ }^{\mathrm{a}} \\
(\%)\end{array}$ \\
\hline 1 & $174.4 \pm 1.89$ & 26 & $91.46 \pm 1.98$ & $88.22 \pm 0.21$ & $93.66 \pm 1.02$ \\
\hline 2 & $302.6 \pm 2.11$ & 14 & $95.57 \pm 2.74$ & $94.10 \pm 0.40$ & $96.71 \pm 4.49$ \\
\hline 3 & $145.5 \pm 1.78$ & 16 & $92.26 \pm 5.89$ & $85.58 \pm 0.45$ & $98.40 \pm 7.00$ \\
\hline 4 & $390.5 \pm 2.06$ & $>45$ & $92.11 \pm 12.89$ & $99.00 \pm 1.80$ & $10.11 \pm 14.93$ \\
\hline 5 & $190.4 \pm 2.84$ & 27 & $96.17 \pm 3.18$ & $95.91 \pm 0.63$ & $97.13 \pm 4.23$ \\
\hline 6 & $152.3 \pm 2.87$ & 28 & $96.77 \pm 3.65$ & $92.28 \pm 0.28$ & $101.59 \pm 2.81$ \\
\hline 7 & $159.6 \pm 3.01$ & 16 & $93.60 \pm 4.61$ & $93.28 \pm 1.17$ & $91.99 \pm 3.03$ \\
\hline 8 & $140.7 \pm 2.10$ & 18 & $95.51 \pm 4.57$ & $96.70 \pm 0.35$ & $99.95 \pm 4.39$ \\
\hline 9 & $148.4 \pm 1.94$ & 20 & $90.26 \pm 4.77$ & $87.97 \pm 0.70$ & $99.30 \pm 5.02$ \\
\hline 10 & $167.5 \pm 2.43$ & 20 & $103.71 \pm 6.36$ & $97.26 \pm 0.19$ & $104.83 \pm 3.80$ \\
\hline 11 & $263.2 \pm 2.16$ & 22 & $87.25 \pm 3.66$ & $88.87 \pm 1.16$ & $93.60 \pm 3.83$ \\
\hline 12 & $194.2 \pm 4.77^{\mathrm{b}}$ & 15 & $86.93 \pm 10.32$ & $89.05 \pm 0.58$ & $94.70 \pm 16.94$ \\
\hline 13 & $220.8 \pm 2.47$ & 26 & $91.84 \pm 1.94$ & $91.78 \pm 0.27$ & $86.81 \pm 2.04$ \\
\hline 14 & $234.7 \pm 2.46$ & 20 & $89.19 \pm 2.77$ & $90.93 \pm 0.26$ & $94.67 \pm 3.40$ \\
\hline 15 & $306.5 \pm 1.90$ & 18 & $106.27 \pm 3.06$ & $105.37 \pm 0.65$ & $109.84 \pm 2.48$ \\
\hline 16 & $205.4 \pm 1.28$ & 19 & $92.62 \pm 2.97$ & $93.49 \pm 0.33$ & $96.49 \pm 6.15$ \\
\hline 17 & $128.6 \pm 4.55^{\mathrm{b}}$ & 14 & $96.58 \pm 6.05$ & $95.96 \pm 0.30$ & $97.63 \pm 4.99$ \\
\hline 18 & $219.5 \pm 4.47$ & 20 & $98.33 \pm 19.67$ & $87.46 \pm 0.97$ & $101.85 \pm 24.63$ \\
\hline 19 & $144.2 \pm 4.81^{\mathrm{b}}$ & 16 & $90.94 \pm 6.24$ & $95.26 \pm 0.84$ & $92.92 \pm 5.88$ \\
\hline 20 & $176.8 \pm 4.46^{\mathrm{b}}$ & 12 & $93.14 \pm 4.88$ & $93.09 \pm 0.27$ & $98.39 \pm 4.69$ \\
\hline 21 & $166.9 \pm 1.50$ & 19 & $92.89 \pm 11.48$ & $90.74 \pm 0.75$ & $97.48 \pm 10.95$ \\
\hline 22 & $157.7 \pm 4.75$ & 26 & $97.18 \pm 16.81$ & $94.25 \pm 0.63$ & $105.68 \pm 15.17$ \\
\hline 23 & $192.6 \pm 1.45$ & 12 & $91.63 \pm 2.23$ & $90.83 \pm 0.80$ & $89.80 \pm 5.84$ \\
\hline 24 & $194.6 \pm 1.43$ & 24 & $89.72 \pm 3.18$ & $88.96 \pm 1.00$ & $98.17 \pm 5.83$ \\
\hline 25 & $132.3 \pm 3.05$ & 16 & $88.50 \pm 4.97$ & $88.03 \pm 1.09$ & $92.59 \pm 2.08$ \\
\hline 26 & $117.9 \pm 2.13$ & 13 & $91.78 \pm 3.18$ & $92.49 \pm 1.25$ & $96.27 \pm 1.88$ \\
\hline 27 & $273.6 \pm 4.33$ & 15 & $92.10 \pm 8.81$ & $101.91 \pm 0.64$ & $96.17 \pm 10.39$ \\
\hline 28 & $172.4 \pm 3.75$ & 16 & $90.52 \pm 8.05$ & $88.23 \pm 1.19$ & $91.88 \pm 11.94$ \\
\hline 29 & $134.9 \pm 1.95$ & 17 & $96.90 \pm 11.49$ & $92.26 \pm 0.10$ & $100.07 \pm 6.46$ \\
\hline 30 & $234.6 \pm 1.98$ & 22 & $95.92 \pm 1.92$ & $96.52 \pm 1.14$ & $100.22 \pm 4.79$ \\
\hline
\end{tabular}

a: mean \pm RSD [(standard deviation/mean)x100]; b: before removal of content; c: maximum time for complete disintegration. 
one batches (70\%) met the criteria 90.0-110.0\% LA $(90.74$ to $105.37 \%)$ and RSD was less than $2.0 \%(0.2$ to $1.8 \%)$. All nine batches (P1, P3, P9, P11, P12, P18, P24, P25, P28) that failed the test showed \%LA less than 90.0 but greater than or equal to $85.5 \%$. In some cases, the problem was due to the fact that a purity correction factor may not have been established for the raw material used.

Dissolution test results (Table IV) were evaluated according to SIM \% average release and RSD values: 27 batches met the acceptance criteria with individual values greater than or equal to $80 \% \mathrm{LA}$ (20 mg SIM). All three batches (P4, P12, P18) that failed the test showed high RSD values $(14.9,16.9,24.6 \%)$. Batch $\mathrm{P} 4$, whose capsules contained a high CMC percentage $(30 \% \mathrm{w} / \mathrm{w})$ showed very low drug release $(\leq 12.7 \%)$ for all units. This suggests a serious formulation problem, leading to a large quality discrepancy and hence, drug inefficacy. In summary, out of 30 , only $14(46.6 \%)$ batches met the requirements for all quality control tests, encoded $\mathrm{P} 2$, P5-8, P13-17, P20, P23, P26, P30. The most common problem was related with content uniformity, occurring in $68.7 \%$ of non-approved batches. This finding represents a major concern for the regulatory authorities since it is related with low quality of powder homogenization and its distribution in the capsules, in an essential practice in compounding pharmacies. The second most frequent problem was observed for SIM assay, which occurred in $56.2 \%$ of non-approved batches. This may possibly be explained by the lack or inappropriate use of a correction factor due to a raw material with lower purity. Low $\%$ SIM release after dissolution test occurred in $18.7 \%$ of non-approved batches. These results are closely related to the content uniformity results, since all such batches also showed high RSD values greater than 10.3\% for content uniformity test. Weight determination and disintegration problems occurred in isolated batches. Therefore, the conditions and acceptance criteria established for pharmaceutical control tests applicable to SIM compounded capsules are important to evaluate the quality of distinct batches traded not only locally, but also, nationwide. These tests and their specifications have been suggested to devise a SIM capsule monograph, as guidance for pharmaceutical quality control of these products to be included in the latest edition of the Brazilian Pharmacopeia. Although drug compounding activities in Brazil have been regulated by ANVISA for the last ten years, by means of several acts and their updates, content uniformity problems can be easily avoided by rigorous quality requirements and personnel training. In addition, considering that each batch had been acquired by one patient, $53.3 \%$ of these individuals would have had their treatment compromised due to lack of quality compliance.

\section{ACKNOWLEDGMENTS}

The authors acknowledge Fapemig and CAPES for funding support, and the Pharmacy undergraduate Amanda Leão dos Santos for laboratory assistance.

\section{REFERENCES}

ANVISA. O X da manipulação. Boletim Informativo, v.56, p.6-9, 2005.

BERTOLLO, G. O processo magistral em farmácias do estado do Espírito Santo. Dissertação. Faculdade de Farmácia, Universidade Federal de Minas Gerais, 2008, p.18.

BRASIL. Lei n ${ }^{\circ} 9.782$, de 26 de janeiro de 1999. Diário Oficial [da] República Federativa do Brasil, Poder Legislativo, Brasília, DF, 27 jan. 1999. Seção I, p.1.

BRASIL. Resolução n ${ }^{\circ} 229$, de 24 de junho de 1999. Diário Oficial [da] República Federativa do Brasil, Poder Executivo, Brasília, DF, 28 jun. 1999a. Seção I, p.17.

BRASIL. Resolução RDC n 33, de 19 de abril de 2000. Diário Oficial [da] União, Poder Executivo, Brasília, DF, 24 abr 2000. Seção I, p.27.

BRASIL. Resolução RDC n 214, de 12 de dezembro de 2006. Diário Oficial [da] União, Poder Executivo, Brasília, DF, $18 \mathrm{dez}$ 2006. Seção I, p.1.

BRASIL. Resolução RDC n 67, de 8 de outubro de 2007. Diário Oficial [da] União, Poder Executivo, Brasília, DF, 09 out 2007. Seção I, p.29-58.

BRASIL. Resolução RDC n 87, de 21 de novembro de 2008. Diário Oficial [da] União, Poder Executivo, Brasília, DF, 24 nov 2008, Seção I, p.58-59.

ERMER, J. Validation in pharmaceutical analysis. Part I: An integrated approach. J. Pharm. Biomed. Anal., v.24, p.755767, 2001.

FARMACOPÉIA Brasileira. 4.ed. São Paulo: Atheneu, 1988. p.V.1.1-V.1.4.

FARMACOPÉIA Brasileira. 4.ed. São Paulo: Atheneu, 1996. p.V.1.6. 
GREEN, J. A practical guide to analytical method validation. Anal. Chem., v.68, p.605A-609A, 1996.

JENKE, D. Chromatographic method validation: a review of current practices and procedures. II. Guidelines for primary validation parameters. J. Liq. Chromatogr. Rel. Technol., v.19, p.737-757, 1996.

ROWE, R. C.; SHESKEY, P. J.; QUINN, M. E. Handbook of pharmaceutical excipients. 6.ed. London: United Kingdom, 2009. p.119.

SHABIR, G. Validation of high-performance liquid chromatography methods for pharmaceutical analysis. Understanding the differences and similarities between validation requirements of the US Food and Drug Administration, the US Pharmacopeia and the International Conference on Harmonization. J. Chromatogr. A, v.987, p.57-66, 2003.

SNYDER, L.; KIRKLAND, J.; GLAJCH, J. Practical HPLC method development. 2.ed. New York: John Wiley, 1997. p.239.
SOUZA, S.; JUNQUEIRA, R. A procedure to assess linearity by ordinary least squares method. Anal. Chim. Acta, v.552, p.25-35, 2005.

The 4S Collaborative Investigators. Randomised trial of cholesterol lowering in 4444 patients with coronary heart disease: the Scandinavian Simvastatin Survival Study (4S). Lancet, v.344, p.1383-1389, 1994.

UNITED states pharmacopeia. Simvastatin tablets. 32.ed. Rockville: United States Pharmacopeia Convention, 2009. p.3558.

UNITED states pharmacopeia. The dissolution procedure: development and validation $<1092>$. 32.ed. Rockville: United States Pharmacopeia Convention, 2009a. p.599.

Received for publication on $17^{\text {th }}$ December 2010 Accepted for publication on $30^{\text {th }}$ May 2011 